\title{
The Role of Morphology during Growth of Mortierella alpina in Arachidonic Acid Production
}

\author{
Nagao Totani* , Ayako Yamaguchi, Miho Yawata and Takashi Ueda \\ Department of Nutritional Physiology, Kobe-Gakuin University \\ (518 Arise, Ikawadani-cho, Nishi-ku, Kobe 651-2180, JAPAN)
}

Edited by T. Itoh, Kitasato Univ., and accepted April 1, 2002 (received for review February 20, 2002)

\begin{abstract}
The filamentous fungus Mortierella alpina was incubated aerobically at $20^{\circ} \mathrm{C}$ for two weeks with shaking in a flask containing liquid medium composed of urea, dextrose, and various minerals including $\mathrm{KH}_{2} \mathrm{PO}_{4}, \mathrm{MgSO}_{4} \cdot 7 \mathrm{H}_{2} \mathrm{O}$ and $\mathrm{CaCl}_{2} \cdot 2 \mathrm{H}_{2} \mathrm{O}$. Urea was found to be as good a source of nitrogen as potato protein only when certain minerals were present in the growth medium. The potassium, phosphorus, and magnesium minerals particularly affected the growth of the fungus. The cell mass yielded was proportional to the amount of $\mathrm{KH}_{2} \mathrm{PO}_{4}$ present in the growth medium while only a small amount of $\mathrm{MgSO}_{4} \cdot 7 \mathrm{H}_{2} \mathrm{O}$ was critical for the growth, although additional amounts of $\mathrm{MgSO}_{4} \cdot 7 \mathrm{H}_{2} \mathrm{O}$ did not increase the cell mass accordingly. Under mild agitation conditions the fungus grew in pulpy form, however, magnesium sulfate pelleted the fungus in the urea medium when potassium dihydrogenphosphate was present in a $\mathrm{KH}_{2} \mathrm{PO}_{4} / \mathrm{MgSO}_{4} \cdot 7 \mathrm{H}_{2} \mathrm{O}$ weight ratio below 1 . Lipid-free cells of the uniform pellets remarkably weighed more than the pulpy form and the arachidonic acid content in fatty acids of the pellet was greater, even though the overall level of fatty acids was lower. The results suggested that the lipid-free uniform pellets consumed much glucose leaving a small amount for lipid synthesis and that in the final stage of the incubation starvation of the fungus accelerated the fatty acid conversion to produce arachidonic acid.
\end{abstract}

Key words: Mortierella alpina, arachidonic acid, pellet, morphology, urea, magnesium, potassium dihydrogenphosphate

\section{Introduction}

We reported (1-3) that Mortierella alpina was an extraordinarily good producer of arachidonic acid when cultivated in natural media and that the fungus accumulated $11.1 \mathrm{~g}$ arachidonic acid/L medium on a pilot-scale cultivation of $300 \mathrm{~L}$ (4). Since then several groups from around the world have studied many issues related to the production of arachidonic acid using M. alpina and natural protein sources such as potato protein powder (5), soy flour (6), and others (7), and cultivations have been established even on a $20-\mathrm{kL}$ scale.

The high yield of arachidonic acid which rapid increase was observed during low glucose concentration in a medium, was always accompanied by the morphological change under high agitation (4). Highly agitated incubation means high physical stress and high oxygen concentration in the medium (7). The effects of dissolved oxygen tension and mechanical forces on fungal morphology were studied in the submerged fermentation of Aspergillus awamori (8) and pellet size and the hairy length of pellets were found to be a function of the mechanical force intensity and to be independent on the dissolved oxygen tension provided that the tension was neither too low nor too high. It is of interest whether the pelleted growth is essential for the high

* Correspondence to: Nagao TotAni, Department of Nutritional Physiology, Faculty of Nutrition, Kobe-Gakuin University, 518 Arise, Ikawadani-cho, Nishi-ku, Kobe 651-2180, JAPAN

E-mail: totani@nutr.kobegakuin.ac.jp 
yield of arachidonic acid. Thus we tried to grow pellets and pulp of the fungus respectively in two simple but similar media without big physical stress and excess oxygen dissolved or supplied.

Besides agitation $(8,9)$, parameters of pellet formation include inoculum level (10-12), medium composition $(9,12,13,32)$, initial $\mathrm{pH}(14)$. Low inoculum levels tended to grow pellets but we could not find the proper conditions for $M$. alpina. In the media containing ammonium sulfate (15), ammonium nitrate (16), and ammonium carbonate (17), Penicillium chrysogenum, Myrothecium verrucaria, and Aspergillus niger grew in pellet morphology respectively. The effect of trace elements on morphology was also widely investigated; manganese for Aspergillus wentii (18), and zinc, iron, manganese, and ferrocyanide for A. niger (17). Chelating agents were another possibility to form pellets.

Since the nutritional requirements of $M$. alpina are high, the growth of the fungus was poor in the media composed of inorganic nitrogen compounds, urea, or amino acids as sources of nitrogen so far. In our previous work using corn peptides in the growth medium, we determined that $\mathrm{P}, \mathrm{K}, \mathrm{Mg}, \mathrm{Ca}, \mathrm{Zn}, \mathrm{Fe}, \mathrm{Mn}$ and $\mathrm{Cu}$ were essential requirements for the fungus (19) but relations between fungal morphology and the mineral balance were not examined. Higashiyama et al. (20) incubated the fungus in the soy flour medium added with $\mathrm{Na}, \mathrm{Ca}$ and $\mathrm{Mg}$ to grow pellets but the natural nitrogen source has too complicated factors to elucidate our problem. In the present study, our strategy was to cultivate $M$. alpina with shaking in urea media containing minerals described above in different ratios in an effort to grow pulpy and pelleted forms and to study the role of the pelleted growth.

\section{Experimental}

\subsection{Materials}

\section{$2 \cdot 1 \cdot 1$ Culture}

The Institute for Fermentation, Osaka, Japan (IFO) supplied $M$. alpina IFO 8568. A stock culture was grown on a potato-dextrose agar slant in a test tube at $20^{\circ} \mathrm{C}$ and subsequently kept at $5^{\circ} \mathrm{C}$ no longer than three weeks prior to inoculation. On inoculation, $3 \mathrm{~mL}$ sterilized water was added to the test tube, mixed well with the mycelia and then filtered through sterilized gauze. One milliliter of the filtrate thus obtained was added to $100 \mathrm{~mL}$ of growth medium.

\section{$2 \cdot 1 \cdot 2 \quad$ Chemicals}

Potato protein powder was a gift from Bayer Ltd. (Tokyo, Japan). Urea and all amino acids were purchased from nacalai tesque, Inc. (Osaka, Japan). Corn peptides, glucose, and all inorganic salts $\left(\mathrm{KH}_{2} \mathrm{PO}_{4}\right.$, $\mathrm{MgSO}_{4} \cdot 7 \mathrm{H}_{2} \mathrm{O}, \mathrm{CaCl}_{2} \cdot 2 \mathrm{H}_{2} \mathrm{O}, \mathrm{FeSO}_{4} \cdot 7 \mathrm{H}_{2} \mathrm{O}, \mathrm{CuSO}_{4} \cdot$ $5 \mathrm{H}_{2} \mathrm{O}, \mathrm{ZnSO}_{4} \cdot 7 \mathrm{H}_{2} \mathrm{O}, \mathrm{MnCl}_{2} \cdot 4 \mathrm{H}_{2} \mathrm{O}$, and $\mathrm{MgCl}_{2} \cdot 6 \mathrm{H}_{2} \mathrm{O}$ ) were products of Wako Pure Chemical Industries Ltd. (Tokyo, Japan).

\subsection{Methods}

\section{$2 \cdot 2 \cdot 1 \quad$ Preparation of medium}

Urea was added to a $100 \mathrm{~mL}$ base mixture containing $6 \mathrm{~g}$ dextrose, minerals (21), the $\mathrm{pH}$ adjusted at 5.6 and autoclaved at $121^{\circ} \mathrm{C}$ for $20 \mathrm{~min}$. Urea was replaced in the growth medium by potato protein powder (5), the nitrogen content of which was $16.0 \%$. As arachidonic acid levels appear not to be affected by the presence of vitamins (Totani, N., unpublished data), they were omitted from the growth medium.

\section{$2 \cdot 2 \cdot 2$ Incubation}

Medium was inoculated with the fungus in a $500-\mathrm{mL}$ flask and shaken at $140 \mathrm{rpm}$ at $20^{\circ} \mathrm{C}$ for 14 days. Under this shaking condition surface of medium was wrapping in air slightly. The cells thus grown were harvested, washed with water, freeze-dried and weighed. All incubations were carried out in duplicate or triplicate.

\section{$2 \cdot 2 \cdot 3$ Residual glucose assay}

Sugar consumption was determined when a pellet and pulp were grown. M.alpina was incubated in a urea medium $(0.1 \mathrm{gN} / \mathrm{L})$ containing $60 \mathrm{~g} / \mathrm{L}$ glucose, $2.5 \mathrm{~g} / \mathrm{L}$ $\mathrm{KH}_{2} \mathrm{PO}_{4}, 2.5 \mathrm{~g} / \mathrm{L} \mathrm{MgSO}{ }_{4} \cdot 7 \mathrm{H}_{2} \mathrm{O}, 75 \mathrm{mg} / \mathrm{L} \mathrm{CaCl} \cdot 2 \mathrm{H}_{2} \mathrm{O}$ and four other minerals as described above except that $3.0 \mathrm{~g} / \mathrm{L} \mathrm{KH}_{2} \mathrm{PO}_{4}$ and $0.5 \mathrm{~g} / \mathrm{L} \mathrm{MgSO}_{4} \cdot 7 \mathrm{H}_{2} \mathrm{O}$ were taken for the growth of the pulpy fungus. Glucose concentrations of the leftover media were assayed using Glucose C II -Testwako (Wako). The medium was sterilized by passage through a $0.2 \mu \mathrm{m}$ cellulose acetate membrane syringe filter, $25 \mathrm{~mm}$ in diameter (Iwaki Glass, Tokyo, Japan) prior to the test.

\section{$2 \cdot 2 \cdot 4$ Fatty acid analysis}

Dried fungus was crushed using a mortar and pestle, followed by the lipid extraction with chloroform/ methanol 2:1 (vol./vol.). The lipid was transesterified with $5 \%$ sodium methoxide-methanol solution. The resultant colorless or pale-yellow transparent methyl esters were analyzed by gas chromatography.

\section{$2 \cdot 2 \cdot 5$ Gas chromatography}


A Shimadzu GC-14A gas chromatograph equipped with a $3.1-\mathrm{m}$ glass column of 3.2-mm bore packed with Shimadzu Shinchrom E71 5\%/Shimalite 80-100 was used. The instrument was fitted with a flame ionization detector.

\section{Results}

\subsection{Estimation of Minerals Needed for the Growth of M. alpina}

The effects of seven salts were tested in growth media containing $1 \mathrm{~g} / \mathrm{L}$ urea (nitrogen content $0.47 \mathrm{~g} / \mathrm{L}$ ) and $60 \mathrm{~g} / \mathrm{L}$ glucose. The salts were present in the following concentrations; $\mathrm{KH}_{2} \mathrm{PO}_{4}, 3 \mathrm{~g} / \mathrm{L} ; \mathrm{MgSO}_{4} \cdot 7 \mathrm{H}_{2} \mathrm{O}, 0.5$ $\mathrm{g} / \mathrm{L} ; \mathrm{CaCl}_{2} \cdot 2 \mathrm{H}_{2} \mathrm{O}, 10 \mathrm{mg} / \mathrm{L} ; \mathrm{FeSO}_{4} \cdot 7 \mathrm{H}_{2} \mathrm{O}, 10 \mathrm{mg} / \mathrm{L}$; $\mathrm{ZnSO}_{4} \cdot 7 \mathrm{H}_{2} \mathrm{O}, 1 \mathrm{mg} / \mathrm{L} ; \mathrm{MnCl}_{2} \cdot 4 \mathrm{H}_{2} \mathrm{O} 1 \mathrm{mg} / \mathrm{L} ; \mathrm{CuSO}_{4} \cdot$ $5 \mathrm{H}_{2} \mathrm{O}, 0.2 \mathrm{mg} / \mathrm{L}$. Additionally, six of the seven minerals were tested separately in an attempt to delineate their individual effect upon fungal growth. The fungus grew very well $(18.2 \mathrm{~g} / \mathrm{L})$ when the seven minerals were added. Each one of the minerals, especially $\mathrm{KH}_{2} \mathrm{PO}_{4}$ and $\mathrm{MgSO}_{4} \cdot 7 \mathrm{H}_{2} \mathrm{O}$, appeared to be essential for fungal growth, while $\mathrm{FeSO}_{4} \cdot 7 \mathrm{H}_{2} \mathrm{O}$ and $\mathrm{ZnSO}_{4} \cdot 7 \mathrm{H}_{2} \mathrm{O}$ were also very influential and $\mathrm{CaCl}_{2} \cdot 2 \mathrm{H}_{2} \mathrm{O}, \mathrm{MnCl}_{2} \cdot 4 \mathrm{H}_{2} \mathrm{O}$, and $\mathrm{CuSO}_{4} \cdot 5 \mathrm{H}_{2} \mathrm{O}$ were needed for the good growth of the fungus.

\section{$3 \cdot 2$ Use of Alternative Nitrogen Sources}

Growth medium of potato protein referred to earlier (5) was prepared and tested as an alternative to urea as the principal nitrogen source. Fungal growth was measured in terms of dry cell weight after a 14-day incubation period (Fig. 1).

Figure 2 shows the amount of methyl esters produced as accumulated lipids per gram of dry cell, while Fig. 3 shows the amount of methyl esters produced per liter of medium. Fungal growth in medium containing urea was comparable to that observed in potato protein medium tested containing up to $4.67 \mathrm{~g}$ nitrogen/L. Fungal growth dropped in medium containing higher levels of urea probably due to the effect of increased osmotic pressure (Fig. 1). By autoclaving of the media urea seems to decompose to ammonia and carbon dioxide to some extent but there was no difference in the yield of dry cell between the two media. Fungal growth proceeds initially while nitrogen and carbon sources are sufficient. When nitrogen and certain sugar are consumed, the fungus metabolizes the remaining sugars,

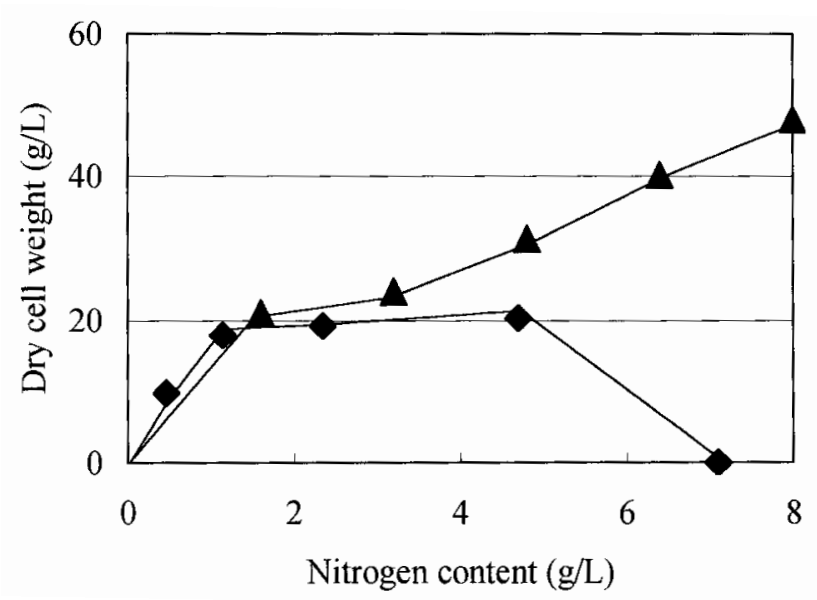

Fig. 1 Cell Growth of Mortierella alpina in Media Containing Urea $(\boldsymbol{)})$ and Potato Protein $(\boldsymbol{\Delta})$.

and lipids accumulate in the cell. In media containing small amounts of nitrogen, lipids begin to accumulate during the early stages of incubation $(4,19)$. Figure 2 shows that high levels of lipids had accumulated after an incubation period of 14 days when a relatively small amount of nitrogen was used. Potato protein medium yielded $48 \mathrm{~g}$ dry cell/L when the initial nitrogen content of the medium was $8 \mathrm{~g} / \mathrm{L}$, however, only $0.06 \mathrm{~g}$ lipids $/ \mathrm{g}$ dry cell had accumulated. This was probably because glucose, present in the medium at $60 \mathrm{~g} / \mathrm{L}$, was predominantly used for cell formation, while leftover glucose

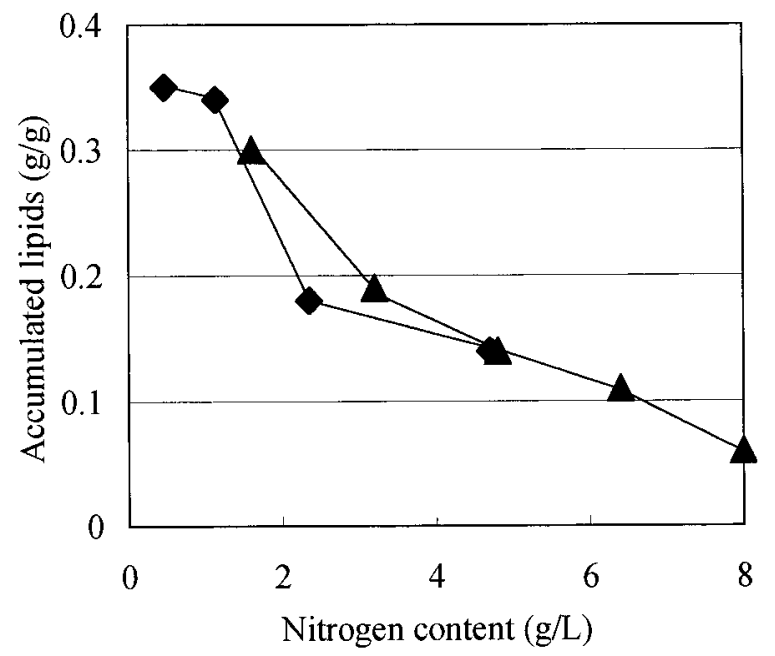

Fig. 2 Lipids Accumulated in Mortierella alpina Grown in Media Containing Urea $(\boldsymbol{)})$ and Potato Protein $(\boldsymbol{\Delta})$. 


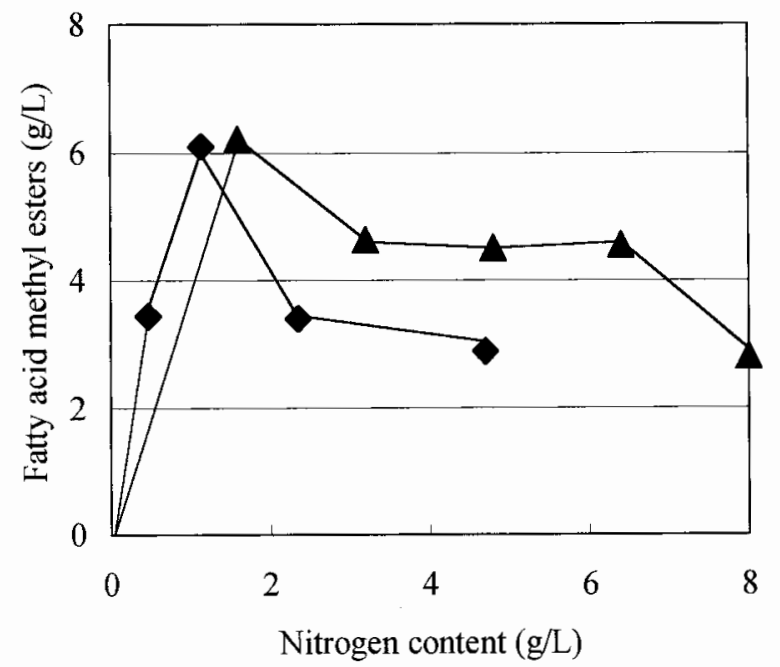

Fig. 3 Yield of Fatty Acid Methyl Esters from Mortierella alpina Grown in Media Containing Urea $(>)$ and Potato Protein $(\mathbf{\Delta})$.

was metabolized to lipids (Figs. 1 and 2). The highest yield of methyl esters was seen in both media that contained an initial nitrogen concentration of about $1 \mathrm{~g} / \mathrm{L}$ (Fig. 3).

\section{$3 \cdot 3 \quad$ Effects of Mineral Salts}

As it was found that $\mathrm{KH}_{2} \mathrm{PO}_{4}$ and $\mathrm{MgSO}_{4} \cdot 7 \mathrm{H}_{2} \mathrm{O}$ were key for the fungal growth, effects of the salts were investigated further. From the data shown in Table 1, $\mathrm{MgSO}_{4} \cdot 7 \mathrm{H}_{2} \mathrm{O}$ present at $0.5 \mathrm{~g} / \mathrm{L}$ resulted in good yields of arachidonic acid.

Only a small amount of $\mathrm{MgSO}_{4} \cdot 7 \mathrm{H}_{2} \mathrm{O}$ was critical for the growth but additional amounts of $\mathrm{MgSO}_{4} \cdot 7 \mathrm{H}_{2} \mathrm{O}$ did not increase the cell mass accordingly. The highest fungal dry cell weight $(18.7 \mathrm{~g} / \mathrm{L})$ was achieved at a $\mathrm{CaCl}_{2} \cdot 2 \mathrm{H}_{2} \mathrm{O}$ concentration of $75 \mathrm{mg} / \mathrm{L}$. The morphology of the fungus grown in urea medium in the absence of $\mathrm{CaCl}_{2} \cdot 2 \mathrm{H}_{2} \mathrm{O}$ consisted of small particles $1 \mathrm{~mm}$ in diameter. Increasing the amount of $\mathrm{MgSO}_{4} \cdot 7 \mathrm{H}_{2} \mathrm{O}$ in the medium changed the morphology from a hairy pellet to a pellet proper.

The effect of $\mathrm{KH}_{2} \mathrm{PO}_{4}$ on fungal growth was then investigated in urea medium containing $2 \mathrm{~g} / \mathrm{L} \mathrm{MgSO}_{4}$. $7 \mathrm{H}_{2} \mathrm{O}$ and $75 \mathrm{mg} / \mathrm{L} \mathrm{CaCl} \cdot 2 \mathrm{H}_{2} \mathrm{O}$ (Fig. 4). The presence of $0.5 \mathrm{~g} / \mathrm{L} \mathrm{KH}_{2} \mathrm{PO}_{4}$ resulted in the formation of only a few pellets of variable size. These pellets had rigid walls.

Increasing the amount of $\mathrm{KH}_{2} \mathrm{PO}_{4}$ in the medium resulted in an increased yield of fungal dry cell weight and the formation of uniform pellets. In a clear pale yellow medium containing $2 \mathrm{~g} / \mathrm{L}$ of $\mathrm{KH}_{2} \mathrm{PO}_{4}$, pellets 2 $\mathrm{mm}$ in diameter was observed. In medium containing 3 $\mathrm{g} / \mathrm{L} \mathrm{KH}_{2} \mathrm{PO}_{4}$, slightly hairy pellets were observed but the number of pellets decreased a little probably due to an increased osmotic pressure. When $\mathrm{MgSO}_{4} \cdot 7 \mathrm{H}_{2} \mathrm{O}$ was reduced to $0.5 \mathrm{~g} / \mathrm{L}$, a small number of rigid pellets were obtained at a $\mathrm{KH}_{2} \mathrm{PO}_{4}$ concentration of $0.5 \mathrm{~g} / \mathrm{L}$, but many hairy, loose pellets and pulp was observed at $\mathrm{KH}_{2} \mathrm{PO}_{4}$ concentrations of $1 \mathrm{~g} / \mathrm{L}$ and $2 \mathrm{~g} / \mathrm{L}$, respectively.

As phosphorus is an important element needed for cell membrane formation, it was no surprise to find that fungal growth was proportional to the amount of $\mathrm{KH}_{2} \mathrm{PO}_{4}$ present in the medium. In media containing urea, the fungus changed its form according to the amounts of $\mathrm{KH}_{2} \mathrm{PO}_{4}$ and $\mathrm{MgSO}_{4} \cdot 7 \mathrm{H}_{2} \mathrm{O}$ present. A delicate balance of minerals needs to be satisfied if the fungus is to grow in a pelleted form.

Table 1 Effects of Minerals on Growth of Mortierella alpina.

\begin{tabular}{ccccccc}
\hline $\begin{array}{c}\mathrm{KH}_{2} \mathrm{PO}_{4} \\
(\mathrm{~g} / \mathrm{L})\end{array}$ & $\begin{array}{c}\mathrm{MgSO}_{4} \cdot 7 \mathrm{H}_{2} \mathrm{O} \\
(\mathrm{g} / \mathrm{L})\end{array}$ & $\begin{array}{c}\mathrm{CaCl}_{2} \cdot 2 \mathrm{H}_{2} \mathrm{O} \\
(\mathrm{mg} / \mathrm{L})\end{array}$ & $\begin{array}{c}\text { Dry cell } \\
\text { weight }(\mathrm{g} / \mathrm{L})\end{array}$ & $\begin{array}{c}\text { Methyl } \\
\text { esters }(\mathrm{g} / \mathrm{g})\end{array}$ & $\begin{array}{c}\text { Methyl arachidonate } \\
\text { content in methyl esters } \\
(\%)\end{array}$ & $\begin{array}{c}\text { Methyl } \\
\text { arachidonate } \\
\text { yield }(\mathrm{g} / \mathrm{L})\end{array}$ \\
\hline 3 & 5 & 0 & 15.3 & 0.300 & 29.7 & 1.36 \\
3 & 2 & 0 & 17.9 & 0.325 & 27.0 & 1.57 \\
3 & 0.5 & 0 & 17.3 & 0.368 & 28.5 & 1.81 \\
3 & 0.1 & 0 & 11.1 & 0.271 & 34.7 & - \\
3 & 0 & 0 & 0 & 0 & - & 1.04 \\
3 & 0.5 & 10 & 18.2 & 0.327 & 28.9 & 2.19 \\
3 & 0.5 & 75 & 18.7 & 0.365 & 32.1 & 0.04 \\
3 & 0.5 & 200 & 1.3 & 0.102 & 28.5 & -1.72 \\
\hline
\end{tabular}

plus $\mathrm{FeSO}_{4} \cdot 7 \mathrm{H}_{2} \mathrm{O} 10 \mathrm{mg} / \mathrm{L} ; \mathrm{ZnSO}_{4} \cdot 7 \mathrm{H}_{2} \mathrm{O} 1 \mathrm{mg} / \mathrm{L} ; \mathrm{MnCl}_{2} \cdot 4 \mathrm{H}_{2} \mathrm{O} 1 \mathrm{mg} / \mathrm{L} ; \mathrm{CuSO}_{4} \cdot 5 \mathrm{H}_{2} \mathrm{O} 0.2 \mathrm{mg} / \mathrm{L}$. 


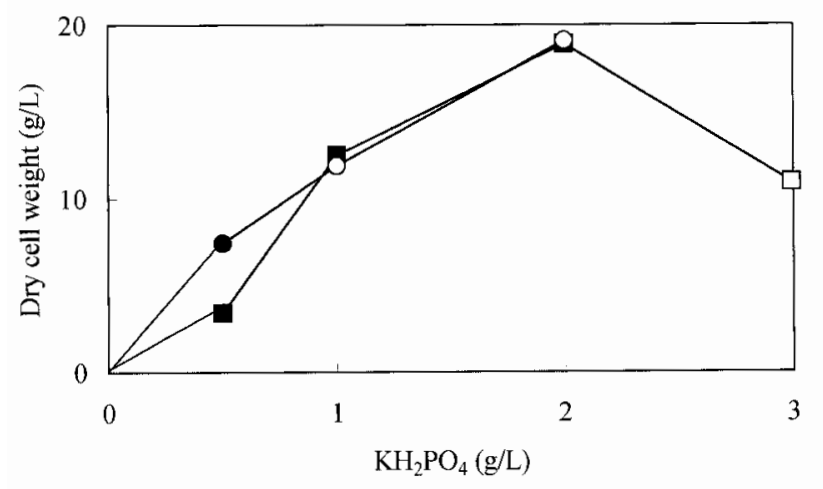

Fig. 4 Effects of Potassium Dihydrogenphosphate on Growth of Mortierella alpina Cultivated in Urea Media Containing $\mathrm{MgSO}_{4} \cdot 7 \mathrm{H}_{2} \mathrm{O} 0.5 \mathrm{~g} / \mathrm{L}$ and $\mathrm{CaCl}_{2}$. $2 \mathrm{H}_{2} \mathrm{O} 75 \mathrm{mg} / \mathrm{L}(\mathrm{O} / \mathrm{O})$ and in That Containing $\mathrm{MgSO}_{4} \cdot 7 \mathrm{H}_{2} \mathrm{O} 2 \mathrm{~g} / \mathrm{L}$ and $\mathrm{CaCl}_{2} \cdot 2 \mathrm{H}_{2} \mathrm{O} 75 \mathrm{mg} / \mathrm{L}(\square /$ 口). and Indicate Pellet.

The effect of $\mathrm{MgSO}_{4} \cdot 7 \mathrm{H}_{2} \mathrm{O}$ on fungal morphology was investigated in urea media containing $\mathrm{KH}_{2} \mathrm{PO}_{4}(0.5$ $3 \mathrm{~g} / \mathrm{L})$ and $\mathrm{CaCl}_{2} \cdot 2 \mathrm{H}_{2} \mathrm{O}(75 \mathrm{mg} / \mathrm{L})$. The results of this analysis are presented in terms of the $\mathrm{KH}_{2} \mathrm{PO}_{4} / \mathrm{MgSO}_{4}$. $7 \mathrm{H}_{2} \mathrm{O}$ weight ratio present in the growth medium (Fig. 5). Clearly, the pelleting effect was strongest at when the weight ratio was about 1 .

Furthermore, the presence of $5 \mathrm{~g} / \mathrm{L} \mathrm{MgSO}{ }_{4} \cdot 7 \mathrm{H}_{2} \mathrm{O}$ in medium containing potato protein powder (nitrogen amount $1 \mathrm{~g} / \mathrm{L})$ and glucose $(60 \mathrm{~g} / \mathrm{L})$ yielded uniform but loose pellets $2 \mathrm{~mm}$ in diameter, but $\mathrm{MgSO}_{4} \cdot 7 \mathrm{H}_{2} \mathrm{O}$ present at $2 \mathrm{~g} / \mathrm{L}$ was less effective. To our knowledge, this is the first reported case of pellet formation in potato protein medium under mild agitation conditions (culture shaken at $140 \mathrm{rpm}$ for 14 days at $20^{\circ} \mathrm{C}$ ). Given that the metabolic pathway taken by the potato proteins and urea would differ, the effect of $\mathrm{MgSO}_{4} \cdot 7 \mathrm{H}_{2} \mathrm{O}$ on these biological systems would also be different. This was evidenced by the resultant differences in fungal morphology obtained with the two cultures. The potato protein medium yielded pulp whilst the urea medium gave rise to clearly defined fungal pellets.

\subsection{Sugar Consumption}

The decrease in glucose concentration was concomitant with an increase in growth of pellets and pulp (Fig. 6) and no big difference was found between the two media. Dry cell weights were $18.2 \mathrm{~g} / \mathrm{L}$ and $18.7 \mathrm{~g} / \mathrm{L}$ for pelleted and pulpy morphologies, respectively.

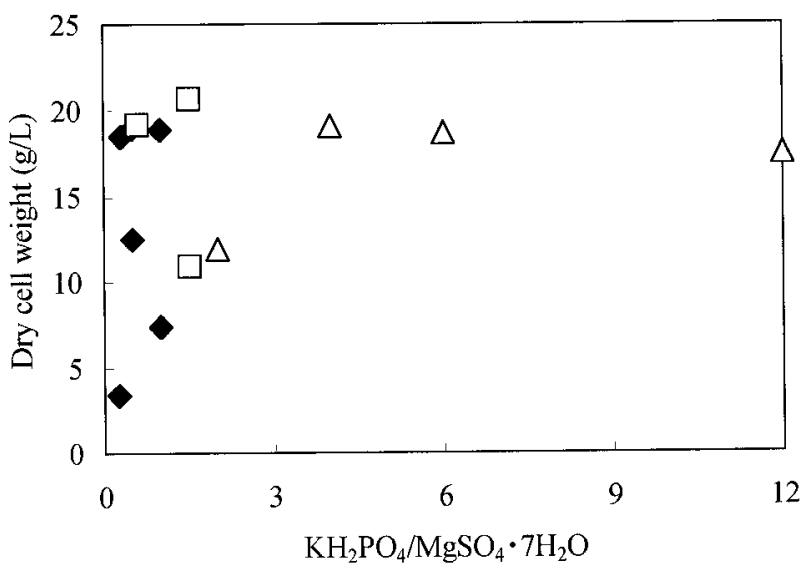

Fig. 5 Effects of Magnesium Sulfate on Growth of Mortierella alpina Cultivated in Urea Medium: pellet, $(\diamond)$; hairy pellet, $(\square)$; pulp, $(\triangle)$.

\subsection{Magnesium Requirement}

$\mathrm{MgSO}_{4} \cdot 7 \mathrm{H}_{2} \mathrm{O}$ was replaced with $\mathrm{MgCl}_{2} \cdot 6 \mathrm{H}_{2} \mathrm{O}$ in an effort to determine the effect of the salt counter-ion on fungal growth. Incubations were carried out as per the residual glucose assay procedure with $\mathrm{MgCl}_{2} \cdot 6 \mathrm{H}_{2} \mathrm{O}$ present at $2.1 \mathrm{~g} / \mathrm{L}$ (a magnesium amount equivalent to $2.5 \mathrm{~g} / \mathrm{L} \mathrm{MgSO}_{4} \cdot 7 \mathrm{H}_{2} \mathrm{O}$ ). This yielded small fungal particles with a cell mass about one ninth of that achieved in medium containing $\mathrm{MgSO}_{4} \cdot 7 \mathrm{H}_{2} \mathrm{O}$.

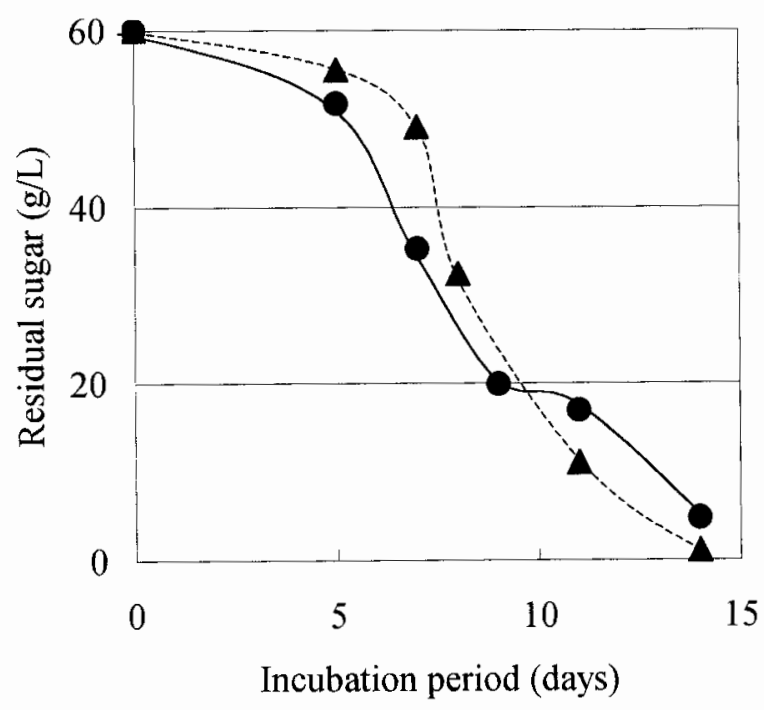

Fig. 6 Sugar Consumption in Cultivation of Mortierella alpina in Pellet (O) and Pulpy (A) Forms. 


\section{Discussion}

Pellets are sometimes said to be unfavorable in productions of amino acids, enzymes (22), and fumaric acid $(23,24)$ on the one hand but opposite views are also present for itaconic acid (25) and fumaric acid productions (26). Previously (4), we reported that increasing the agitation speed from 100 to $500 \mathrm{rpm}$ in medium containing $2 \%$ wheat bran, $1 \%$ peptone, and $10 \%$ glucose changed the morphology of M. alpina from a pulp to a pellet. This also had the effect of increasing the dry cell weight from $32.0 \mathrm{~g} / \mathrm{L}$ to $46.2 \mathrm{~g} / \mathrm{L}$ and increasing the methyl ester content from 6.63 to $14.9 \mathrm{~g} / \mathrm{L}$ and the relative methyl arachidonate levels also from 36.6 to $71.1 \%$. Production of arachidonic acid and the yield of accumulated lipids became more than four-fold and 1.56 times higher, respectively under these conditions. High enough air supply to the medium enhanced the growth of the fungus and fatty acid unsaturation; it is also true that the more cells grow the more lipids are synthesized and accumulated as long as glucose is existing in the medium. But the initial glucose concentration described above was too high for the fungus to grow in a good yield in the shake flask study. Hiruta $e t$ al. (10) also reported that Motierella ramanniana pro- duced increased levels of $\gamma$-linolenic acid in a 30-L jar fermentor and 10-kL fermentor at high agitation speeds.

Urea proved to be an effective nitrogen source for M. alpina and comparable to potato protein provided it was used at concentrations below $10 \mathrm{~g} / \mathrm{L}$ (nitrogen content $4.67 \mathrm{~g} / \mathrm{L}$ ). Growth of the fungus in urea medium needed to be fortified by the addition of $\mathrm{K}, \mathrm{P}, \mathrm{Mg}, \mathrm{Ca}$, $\mathrm{Zn}, \mathrm{Fe}, \mathrm{Mn}$ and $\mathrm{Cu}$.

Under the mild agitation conditions such as shaking in a flask or tube, the fungus tended to grow in pulpy form regardless of the type of media used.

The results presented in Table 2 clearly indicate that the morphology of the fungus changed from pulp to pellet when $\mathrm{MgSO}_{4} \cdot 7 \mathrm{H}_{2} \mathrm{O}$ was present in excess of $\mathrm{KH}_{2} \mathrm{PO}_{4}$ (see also Figs. 4 and 5). Urea medium containing high amounts of the aforementioned two minerals (for example, $2 \mathrm{~g} / \mathrm{L}$ each) grew uncountable pellets uniform in size and appearance. On the other hand, urea medium containing small amounts of the two minerals (for example, $0.5 \mathrm{~g} / \mathrm{L}$ each) grew unevenly-sized pellets whose surface was harder than the pellets grown at minerals concentrations of $2 \mathrm{~g} / \mathrm{L}$. The medium containing a mineral weight ratio greater than 1 yielded a pulpy fungus. Thus pellet formation ideally occurred with a mineral weight ratio below 1 and while the amounts of both

Table 2 Growth of Mortierella alpina and Weight Ratio of $\mathrm{KH}_{2} \mathrm{PO}_{4} / \mathrm{MgSO}_{4} \cdot 7 \mathrm{H}_{2} \mathrm{O}$.

\begin{tabular}{|c|c|c|c|c|c|c|c|}
\hline$\frac{\mathrm{KH}_{2} \mathrm{PO}_{4}}{\mathrm{MgSO}_{4} \cdot 7 \mathrm{H}_{2} \mathrm{O}}$ & $\begin{array}{c}\mathrm{KH}_{2} \mathrm{PO}_{4} \\
(\mathrm{~g} / \mathrm{L})\end{array}$ & $\begin{array}{c}\mathrm{MgSO}_{4} \cdot 7 \mathrm{H}_{2} \mathrm{O} \\
(\mathrm{g} / \mathrm{L})\end{array}$ & $\begin{array}{c}\text { Dry cell } \\
\text { weight } \\
(\mathrm{DCW})(\mathrm{g} / \mathrm{L})\end{array}$ & $\begin{array}{c}\text { Methyl } \\
\text { esters }(\mathrm{g} / \mathrm{g})\end{array}$ & $\begin{array}{c}\text { DCW-Methyl } \\
\text { esters (g/L) }\end{array}$ & $\begin{array}{c}\text { Methyl arachidonate } \\
\text { content in methyl esters } \\
(\%)\end{array}$ & Morphology \\
\hline$\infty$ & 3 & 0 & 0 & 0 & 0 & - & - \\
\hline 30 & 3 & 0.1 & 12.8 & 0.326 & 8.62 & 30.8 & Hairy pellet \\
\hline 12 & 3 & 0.25 & 17.5 & 0.387 & 10.73 & 33.0 & Pulp \\
\hline 6 & 3 & 0.5 & 18.7 & 0.365 & 11.88 & 32.1 & Pulp \\
\hline 4 & 2 & 0.5 & 19.1 & 0.367 & 12.09 & 28.8 & Pulp \\
\hline 2 & 1 & 0.5 & 11.9 & 0.161 & 9.98 & 30.2 & Hairy pellet \\
\hline 1.5 & 3 & 2 & 20.7 & 0.211 & 16.33 & 29.5 & Hairy pellet \\
\hline 1 & 2 & 2 & 18.9 & 0.163 & 15.82 & 42.2 & Pellet $^{1}$ \\
\hline 1 & 1.5 & 1.5 & 18.9 & 0.154 & 15.99 & 39.8 & Pellet $^{2}$ \\
\hline 1 & 0.5 & 0.5 & 7.4 & 0.133 & 6.42 & 23.5 & Pellet $^{3}$ \\
\hline 0.5 & 1.5 & 3 & 19.0 & 0.152 & 16.11 & 40.0 & Pellet $^{2}$ \\
\hline 0.5 & 1 & 2 & 12.5 & 0.132 & 10.85 & 22.3 & Pellet $^{3}$ \\
\hline 0.3 & 1.5 & 5 & 18.5 & 0.156 & 15.61 & 46.2 & Pellet $^{1}$ \\
\hline 0.25 & 0.5 & 2 & 3.4 & 0.072 & 3.16 & 21.0 & Pellet $^{3}$ \\
\hline 0 & 0 & 2 & 0 & 0 & 0 & - & - \\
\hline
\end{tabular}

plus $\mathrm{CaCl}_{2} \cdot 2 \mathrm{H}_{2} \mathrm{O} 75 \mathrm{mg} / \mathrm{L} ; \mathrm{FeSO}_{4} \cdot 7 \mathrm{H}_{2} \mathrm{O} 10 \mathrm{mg} / \mathrm{L} ; \mathrm{ZnSO}_{4} \cdot 7 \mathrm{H}_{2} \mathrm{O} 1 \mathrm{mg} / \mathrm{L} ; \mathrm{MnCl}_{2} \cdot 4 \mathrm{H}_{2} \mathrm{O} 1 \mathrm{mg} / \mathrm{L} ; \mathrm{CuSO}_{4} \cdot 5 \mathrm{H}_{2} \mathrm{O} 0.2 \mathrm{mg} / \mathrm{L}$.

${ }^{1} 1 \sim 2 \mathrm{~mm}^{\varnothing}$, uniform ; ${ }^{2} 3 \sim 7 \mathrm{~mm}{ }^{\varnothing}$, uniform ; ${ }^{3} 2 \sim 10 \mathrm{~mm}$, uneven. 
$\mathrm{KH}_{2} \mathrm{PO}_{4}$ and $\mathrm{MgSO}_{4} \cdot 7 \mathrm{H}_{2} \mathrm{O}$ were between 1.5-5 g/L.

It was also found that the yield of accumulated lipids was about a half in the pellets as Yanagita (30) described that product from the secondary metabolism in pelleted fungus decreased in amount drastically as compared with pulpy fungus. As the highly agitated medium achieved high lipid accumulation per g dry pellet (4), comparable to that of pulp the rigid surface of the pellets was not a critical factor for the fungus to absorb glucose from the medium. In addition the pellets obtained in this study were looser in most cases than the ones grown under high agitation speeds. This observation is consistent with the result of Cui et al. (8)

Most of carbon source was consumed in both cultures (Fig. 6) and dry cell weights of the pellets were comparable with those of pulp. But the weight of lipidfree cells (dry cell weight $(\mathrm{g} / \mathrm{L})$ - accumulated lipids $(\mathrm{g} / \mathrm{L}))$ was greater in the pelleted fungus than in the pulp. Thus in the pellet less amount of remaining glucose was used for lipid synthesis that occurs gradually posterior to cellular growth. And it is likely that the fungus in pellet form suffered glucose depletion in transition phase and thereafter and consumed the lipids accumulated in the cell by that time resulting in elevated level of arachidonic acid $(2,4)$.

As fungi are aerobic microorganisms oxygen is essential for the growth. In addition oxygen is needed for desaturation of fatty acids in the cell. The high agitation supplies much oxygen for a medium (27), thus enhancing the $\mathrm{O}_{2}$ and NADH-dependent enzymatic desaturation of fatty acids (28). Fujikawa et al. (29) carried out agitated incubation of $M$. alpina under increased air pressure and with air rich in oxygen concentration, respectively and found out that 10-15 ppm of average dissolved oxygen concentration was the best for the production of arachidonic acid. As oxygen concentration in water saturated with air of 1 bar was 8.4 ppm at $25^{\circ} \mathrm{C}(8)$ the optimum concentration is very close to it. Slight increase in oxygen concentration of the medium would produce lipids with elevated levels of arachidonic acid. In the present study it remains to be determined if the pellets grown in the urea medium increased oxygen concentration of the medium promoting the desaturation described above.

Koike et al. (31) investigated the influence of the consumed carbon to nitrogen $(\mathrm{C} / \mathrm{N})$ ratio on arachidonic acid production and mycelial morphology in cultures of $M$. alpina using shake flasks and a fermentor. They concluded that lipid biosynthesis was most active when the $\mathrm{C} / \mathrm{N}$ ratio was in the range of 15-32. The ratio of our urea medium was 24, proper for our purpose.

$\mathrm{MgCl}_{2} \cdot 6 \mathrm{H}_{2} \mathrm{O}$ acted as a poor substitute to $\mathrm{MgSO}_{4}$. $7 \mathrm{H}_{2} \mathrm{O}$ in yielding the pelleted form of the fungus. The chloride ion seemed to inhibit the growth of the fungus. Essentially, the fungus requires magnesium ions but the influence of the anion in the mineral cannot be ignored.

\section{Conclusion}

It is summarized that morphology change of $M$. alpina from pulp to pellet form was achieved in a shaking culture only by adjusting the mineral balance, especially the weight ratio of $\mathrm{KH}_{2} \mathrm{PO}_{4} / \mathrm{MgSO}_{4} \cdot 7 \mathrm{H}_{2} \mathrm{O}$ in growth medium. In addition the yield of the pellet was comparable to that of pulpy fungus grown in the same medium except the weight ratio although the overall level of accumulated fatty acids in the pelleted fungus was lower than in the pulp. The role of the pelleted growth in arachidonic acid production was concluded, at least in part, to be increase in the amount of lipid-free cells, resulting in increased glucose consumption for the cell growth and in elevated levels of arachidonic acid which was actively converted from coexisting fatty acids under starvation $(2,4)$.

\section{Acknowledgments}

This study was supported in part by a fund from High Technology Research Center, The Graduate School of Food and Medicinal Sciences, Kobe-Gakuin University. We thank Mayuki Matsushita for her enthusiastic technical assistance.

\section{References}

1. Totani, N., Kudo, T. and Suzaki, K. Japan Patent, 2138405.

2. Totani, N. and Oba, K. (1987) LIPIDS, 22, 1060-1062.

3. Totani, N. and Oba, K. (1988) Appl. Microbiol. Biotech., 28, 135-137.

4. Totani, N., Someya, K. and Oba, K. (1992) Industrial Applications of Single Cell Oils, Am. Oil Chem. Soc., pp. 52-60.

5. Totani, N., Hyodo, K., Yamaguchi, A. and Ueda, T. (2000) J. Jpn. Oil Chem. Soc., 49, 479-485.

6. Higashiyama, K., Yaguchi, T., Akimoto, K., Fujikawa, S. and Shimizu, S. (1998) J. Am. Oil Chem. Soc., 75, 1501-1505.

7. Park, E.Y., Koike, Y., Higashiyama, K., Fujikawa, S. and Okabe, M. (1999) J. Biosci. Bioeng., 88, 61-67. 
8. Cui, Y. Q., van der Lans, R.G.J.M. and Luyben, K.C.A.M. (1997) Biotech. Bioeng., 55, 715-726.

9. Metz, B. and Kossen, N.W.F. (1977) Biotechnol. Bioeng., 19, 781-799.

10. Hiruta, O., Futamura, T., Takebe, H., Satoh, A., Kamisaka, Y., Yokochi, T., Nakahara, T. and Suzuki, O. (1996) J. Ferment. Bioeng., 82, 366-379.

11. Tucker, K.G. and Thomas, C.R. (1992) Biotechnol. Lett., 14, 1071-1074.

12. Xu, J., Wang, L., Ridgway, D., Gu, T. and Moo-Young, M. (2000) Biotechnol. Prog., 16, 222-227.

13. Whitaker, A. and Long, P.A. (1973) Proc. Biochem., 8, 27-31.

14. Wainright, M.P., Trinci, A.J.P. and Moor, D. (1992) Mycological Res., 95, 801-806.

15. Pirt, S. and Callow, D.S. (1959) Nature, 184, 307-310.

16. Darby, R.T. and Mandels, G.R. (1954) Mycologia, 46, 276- 282.

17. Snell, R.L. and Schweiger, L.B. (1949) US Patent 2,492,667.

18. Karrow, E.O. and Waksmann, S.A. (1947) Ind. Eng. Chem., 39, 821- 827.

19. Totani, N., Hyodo, K. and Ueda, T. (2000) J. Jpn. Oil Chem. Soc., 49, 487-493.

20. Higashiyama, K., Yaguchi, T., Akimoto, K., Fujikawa, S. and Shimizu, S. (1998) J. Am. Oil Chem. Soc., 75, 1815-1819.

21. Totani, N., Hyodo, K. and Ueda, T. (2000) J. Jpn. Oil Chem.
Soc., 49, 487-493.

22. Calam, C.T. (1976) Process Biochem., 11, 7-13.

23. Rhodes, R.A., Moyer, A. J., Smith, M.L. and Kelley, S.E. (1959) Appl. Microbiol., 7, 74-80.

24. Rhodes, R.A., Lagoda, A.A., Misenheimer, T.J., Smith, M.L., Anderson, R.F. and Jackson, R.W. (1962) Appl. Microbiol., 10, 9-16.

25. Metz, B., Kossen, N.W.F. and Van Suizdam, J.C. (1979) $A d v$. Biochem. Eng., 11, 103-109.

26. Zhou, Y., Du, J. and Tsao, G.T. (2000) Appl. Biochem. Biotech., 84-86, 779-789.

27. Higashiyama, K., Murakami, K., Tsujimura, H., Matsumoto, N. and Fujikawa, S. (1999), Biotechnol. Bioeng., 63, 442-448.

28. Voet, D. and Voet, J. (1995) Biochemistry, John Wiley \& Sons, Inc., 589-590.

29. Fujikawa, S., Higashiyama, K. and Shimizu, S. (1999) Biosci. Bioindustry, 57, 818-821.

30. Yanagita, T. (1985) Biseibutukagaku, Gakkai-shuppan-senta, pp. 340-347.

31. Koike, Y., Cai, H.J., Higashiyama, K., Fujikawa, S. and Park, E.Y. (2001) J. Biosci. Bioeng., 91, 382-389.

32. Byrne, G.S. and Ward, O.P. (1989) Biotech. Bioeng., 33, $912-$ 914. 